\title{
Giant chorioangioma of placenta: an infrequent placental cause for adverse feto-maternal outcome
}

\author{
Sheeba Marwah*, Neha Bansal, Harsha Gaikwad, Manjula Sharma
}

Department of Obstetrics \& Gynecology, VMMC \& Safdarjang Hospital, New Delhi-110029, India

Received: 28 March 2015

Accepted: 09 May 2015

\author{
*Correspondence: \\ Dr. Sheeba Marwah, \\ E-mail: sheebamarwah@yahoo.co.in
}

Copyright: (c) the author(s), publisher and licensee Medip Academy. This is an open-access article distributed under the terms of the Creative Commons Attribution Non-Commercial License, which permits unrestricted non-commercial use, distribution, and reproduction in any medium, provided the original work is properly cited.

\begin{abstract}
Chorioangioma is a relatively rare benign tumor of placenta arising from chorionic tissue, with incidence being 1 in 100 cases. Giant vascular chorioangiomas render a challenge to obstetricians with their potential critical complications adversely altering feto-maternal outcome. Diagnosis is suspected antenatally by ultrasound and Doppler studies, and is corroborated by histopathology post-delivery. Here we report a pregnancy complicated by a giant placental chorioangioma with polyhydraminos in a young mother, diagnosed prenatally, and associated with deranged liver function tests, culminating into a preterm delivery of a plethoric stillborn fetus, followed by lifethreatening postpartum hemorrhage in mother. Also clinical considerations and relevant literature review on prognostic factors affecting obstetric outcome are addressed. A case of giant chorioangioma placenta warrants close antenatal surveillance and institutional delivery as it may have untoward maternal complications as was seen. Vascularization of tumor is a pivotal determining factor of pregnancy outcome.
\end{abstract}

Keywords: Giant placental chorioangioma, Feto-maternal outcome

\section{INTRODUCTION}

Chorioangiomas, also known as placental hemangiomas, are benign hamartomatous placental growths comprising vascular tissue reported to be present in $\sim 1 \%$ of cases. However, giant chorioangiomas (diameter $>5 \mathrm{~cm}$ ) are very rare with an incidence of 1/10000-1/50000 pregnancies. ${ }^{2}$ Their origin is attributed to capillary dysvasculogenesis. Typically small tumors are clinically insignificant and usually asymptomatic. In contrast, the giant and vascular tumors are notorious for causing unfavorable upshots on both mother and fetus. They cause maternal complications like preterm labor, placental abruption, polyhydramnios, and fetal complications like fetal hydrops, intrauterine growth restriction (IUGR), fetal anemia, cardiac failure, and even fetal demise. ${ }^{3}$ Perinatal mortality has been reported in about $30-40 \%$ cases. ${ }^{4}$ Therefore, prenatal diagnosis is vital to follow up these pregnancies diligently. Diagnosis is suspected antenatally by ultrasound and Doppler studies and is confirmed by histopathology post-delivery. The present article describes a case with a giant placental chorioangioma that had adverse feto-maternal consequences. Also clinical considerations and relevant literature review on prognostic factors affecting outcome are addressed.

\section{CASE REPORT}

A 23 year old Primigravida at 28wks Gestational Age (GA) referred to Safdarjung hospital from a local dispensary with history of jaundice for one week, leaking per vaginum for one day associated with history of decreased fetal movements. In the present pregnancy, she had undergone an USG in early pregnancy that showed a viable intrauterine fetus corresponding to 11 weeks' GA. An anomaly scan at 20 weeks' gestation was unremarkable and the pregnancy continued till 27 weeks' 
GA uneventfully. Subsequently, USG carried out suggested a normal fetus corresponding to GA with an increased amount of liquor. The placenta was enlarged hyper-echoic, in the upper segment showing grade one maturity. The placenta measured $15.5 \mathrm{~cm}$ in transverse diameter, with hypo and hyper-echoic areas, suggestive of placental tumor, possibly a placental chorioangioma.

On examination, patient's vital signs were within normal range, though mildly icteric. Abdominal examination revealed a tense irritable non-tender abdomen with a single fetus in longitudinal lie and breech presentation. Fetal heart sound could not be localized by stethoscope. Liquor seemed clinically increased. On per speculum examination, vaginitis was present without any visible leaking. She was then admitted for further workup and necessary consents were taken. Antibiotics were given. A medical referral was then sought for in view of jaundice, and USG done to confirm fetal wellbeing. Her liver function tests were mildly deranged with AST/ALT being five times normal. However, USG of liver was normal, as was a full hepatitis, infection and autoantibody screen. Bile acids, hematocrit, renal function and glucose tolerance tests, were also within normal limits. Her blood group was A Positive. USG pelvis showed a single dead fetus of 28 weeks 3 days GA in breech presentation with no fetal abnormality, with gross polyhydramnios (AFI 33). Also, placenta was enlarged measuring $15 \times 12 \times 6 \mathrm{~cm}$ with a well-defined growth arising from the fetal surface of the placenta (predominantly hypo-echoic) with multiple cystic areas. Duplex Doppler evaluation of the mass showed an arterial flow pattern. This finding suggested Chorioangioma (Figure 1). Patient went into spontaneous preterm labor followed by assisted breech delivery on day 3 of admission after 4 hours of short labor. The baby was plethoric stillborn boy weighing 900 gm with generalized edema. The placenta weighed 1540 $\mathrm{g}$ and was soft and friable, with a $15 \times 12 \mathrm{~cm}$ lobulated mass on the fetal surface extending into the placental substance. No retro-placental clot was seen. The threevessel umbilical cord with $18 \mathrm{~cm}$ in length and $0.9 \mathrm{~cm}$ in diameter was eccentrically placed. HPE showed a lesion comprising of numerous small vascular channels with prominent endothelial tissues and inter-villous fibrin deposition, supported by inconspicuous loose stroma. There was wide ischemic necrosis. The histologic evaluation was consistent with chorioangioma.

Thereafter patient had postpartum hemorrhage, managed initially with drugs and bimanual compression; but when it turned intractable, balloon tamponade was done. She was transfused two units of packed cells, besides fluids for volume replacement. Fall in LFTs post-delivery were a reflection of mirror syndrome. Her further postpartum period went uneventful. Her liver function tests returned to normal post delivery, and she was discharged in satisfactory condition after three days. At this writing, about six months after her delivery, the mother has recuperated from the loss well and has been doing fine since then.

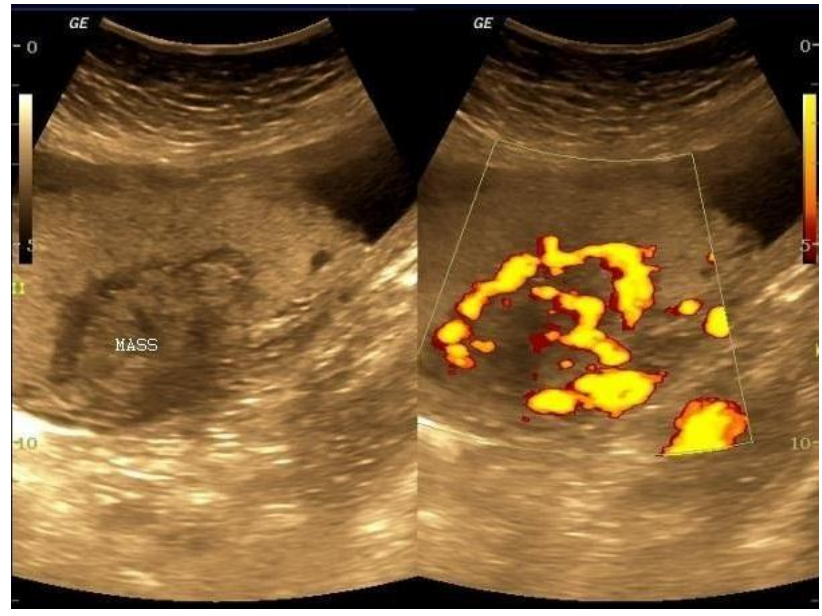

Figure 1: The giant placental chorioangioma on ultrasound.

\section{DISCUSSION}

\section{Pathogenesis and pathology}

Chorioangioma is the commonest non-trophoblastic tumor of placenta with frequency of 1 per 100 placentas. It is most likely hamartoma of primitive chorionic mesenchyme. Only fifty percent are detected during prenatal period. ${ }^{5}$ Moreover, its incidence rises with maternal age and is more prevalent in multiple gestation. Also, there are more female babies with angiomas in their placenta. ${ }^{5}$ Chorioangioma is thought to arise by day16 of fertilization, although there is no documentation of tumor in first trimester. HPE is consistent with a benign angioma arising from chorionic tissue. Ogino and redline have further classified villous capillary lesions of placenta into chorioangioma, chorioangiomatosis and chorioangiosis depending upon size and number. ${ }^{6}$ Ultrastructural studies illustrate chorioangioma and chorioangiomatosis to be lesions of mature stem villi (suggesting earlier gestational origins) whereas chorioangiosis to be a lesion of terminal villi (suggesting an anon derivation). In the present case, HPE was assenting of chorioangioma. Furthermore, three patterns of chorioangiomas have been described by Marchetti: ${ }^{7}$ angiomatous, cellular, and degenerate - angiomatous being the most recurrent, with numerous small areas of endothelial tissue, capillaries, and blood vessels surrounded by placental stroma. These lesions are thus classified as placental hamartomas rather than true neoplasia, sans any malignant potential.

\section{Clinical features and complications}

Trivial angiomas overlooked during prenatal sonography, can only be established by careful pathologic examination. Larger chorioangiomas $(>5 \mathrm{~cm})$, particularly when rapidly growing, are associated with negative clinical impact. ${ }^{8,9}$ This consensus in literature about the association between the chorioangioma size and its clinical manifestations was replicated in our case. 
Maternal complications observed are preeclampsia, preterm labour, placental abruption, and polyhydramnios. ${ }^{10}$ Although the underlying pathophysiology for these difficulties has not been fully elucidated, a conspicuous role for arteriovenous shunting and sequestration of red blood cells and platelets by tumor have been postulated. ${ }^{8-11}$ This leads to hemolysis, microangiopathic anemia, and reduced oxygen carrying capacity of blood, leading to hydrops. High output heart failure is main reason for neonatal mortality (30-40\%). Feto-maternal hemorrhage across tumor capillaries leads to elevated AFP levels in maternal blood and possible maternal hemolysis. Polyhydramnios, as in present case, has been attributed to surfeit amniotic fluid transudate through walls of abnormal tumor vessels, or due to mechanical obstruction of umbilical vein by large tumor mass. ${ }^{12,13}$ Preterm delivery, as in index case, is a common sequel of hydraminos. ${ }^{14} \mathrm{PPH}$ is a well-known complication in mother as was present in our case. Rupture of tumor sinusoids causing sudden deterioration, while spontaneous degeneration and calcification of tumor leads to regression of symptoms. IUGR is another expected problem, because proper blood supply cannot be achieved by the fetus, as reported in various studies. ${ }^{12,13}$ Neonatal morbidity and mortality rates are high because of prematurity and metabolic changes resulting from vascular growth of the placenta. These include congenital anomalies, fetal thrombocytopenia, and hemolytic anemia.

\section{Diagnosis}

Prenatal diagnosis is not difficult. Elevated maternal serum AFP levels during the second trimester screening may also alarm about the possibility of the placental angioma. Greyscale ultrasound examination, first described in 1978 for chorioangiomas, followed by color Doppler imaging confirms the diagnosis. ${ }^{15}$ These findings are well-defined complex echogenic mass different from the rest of placenta and tumor protrudes into amniotic cavity near umbilical cord insertion. Jauniaux et al. used color Doppler imaging for confirmation of diagnosis of placental tumors in nine cases. Colour flow and powerDoppler have made diagnosis more specific, and have allowed the vascularity of the tumor to be assessed and detection of angiomatous, cellular and degenerative changes. ${ }^{16}$ Placental MRI has recently been reported as being used as an adjunct to ultrasound placental imaging. ${ }^{17}$ This modality is safe in pregnancy, offers information about the maternal anatomy, the placental site and it has an ability to differentiate between different placental pathologies by $\mathrm{T}$ weighting of the image. It may offer additional information to the clinician, guiding the management of such cases. ${ }^{18-20}$ In our case, diagnosis was clinched on USG findings itself.

\section{Ballantyne syndrome}

This syndrome, that has acquired various eponyms (Mirror syndrome, pseudo toxaemia, triple oedema and maternal hydrops syndrome) is a condition, characterised by fetal, placental and maternal oedema, often associated with hypertension and proteinuria. Though initially reported in cases of Rhesus isoimmunisation, it has been associated recently with cases of non-immune fetal hydrops as well. Postulated mechanisms are overproduction of HCG, 'hyperplacentosis' and a 'highly potent systemic and renal vasodilator unique to pregnancy' not as yet identified. Common features included low haemoglobin and haematocrit in presence of raised uric acid, hypertension and significant proteinuria. A diagnosis is achieved antenatally with the aid of colour Doppler ultrasound. In the index case, this was absent.

\section{Differential diagnosis}

Chorioangioma is often muddled with placental teratoma/hematoma, degenerated myoma uteri, and hematomas. USG is the main tool used to delineate the same by demonstration of vascular channels similar to fetal vessels. Placental teratomas are cystic avascular solid masses with calcifications. Echogenicity of hematomas differs with time as the coagulation process occurs, while chorioangioma remains the same. Partial mole has diffuse pattern, and myoma is seen on maternal surface. In the concurrent case, there was abundant blood flow in the lacunae of placental tumor telltale of angioma.

\section{Management}

There have been several contemporary reviews of the literature examining the treatment in this potentially morbid condition ${ }^{13,18,21}$ but no treatment has been established superior to other. Existing prenatal treatment options are either supportive or definitive. Supportive measures include serial fetal intrauterine transfusions for fetal anemia, and amnioreduction through therapeutic amniocentesis/maternal transplacental pharmacotherapy with indomethacin. ${ }^{13,22,23}$ Steroid administration for acceleration of fetal lung maturity before 34 weeks is also indicated. Definitive endoscopic surgical devascularisation (ligation/clipping, fetoscopic laser ablation, embolization, chemosclerosis with absolute alcohol injection) and radiofrequency ablation of tumor vessels can be performed. ${ }^{24}$ However, therapy is only contemplated only when there are USG features of fetal compromise and gestation is non-viable. Small asymptomatic tumors can be managed expectantly at least every month for small tumors and every 1-2 weeks for the greater ones. The key point in the follow-up of these patients is to keep in mind that at any time the fetus can get distress, and at any time fetal hydrops and fetal congestive heart failure can occur. The proper timing of labor is controversial and primarily depends on the fetomaternal complications. Our patient was an unbooked case WITH IUD and delivered within 72 hours of admission; so nothing much could be done.

\section{Prognostic factors}

Giant chorioangiomas $(>5 \mathrm{~cm})$ like the index case, associated with polyhydramnios cause high perinatal 
morbidity and mortality. Polyhydramnios and fetal cardiomegaly are the most striking ominous outcomes, followed by hydrops fetalis and IUGR. Besides, Jauniaux et al. concluded that vascularization of the tumor is a pivotal determining factor of pregnancy outcome. ${ }^{15}$ The more vascular the tumor, the worse the perinatal outcome (as in our case).

\section{CONCLUSION}

While the incidence of giant placental chorioangiomas is relatively low, its diagnosis and management represents a stringent challenge due to its potentially serious antenatal complications adversely affecting pregnancy outcome. This underlines the importance of early diagnosis and individualized assessment. High fetal death in these cases warrants institutional and timely delivery, as was seen in our case. Antenatal diagnosis is done by USG, and Doppler would have been the investigation of choice in accurate prompt diagnosis. Regular follow-up of patients also assists in timely diagnosis and possible intervention required.

\section{ACKNOWLEDGEMENTS}

Our patient, who fought bravely the tumor and its outcomes, and allowed us to evaluate her in detail for a better understanding of these tumors.

Funding: No funding sources Conflict of interest: None declared

Ethical approval: Not required

\section{REFERENCES}

1. Burcu Artunc Ulkumen, Halil Gursoy Pala, Nalan Nese, Yesim Baytur. Prenatal diagnosis and fetomaternal outcomes of two cases with placental chorioangioma. Case Rep Obstet Gynecol. 2013;2013:926743.

2. Bassel H. Al Wattar, Sarah C. Hillman, Tamas Marton, Katharine Foster, Mark D. Kilby. Placenta chorioangioma: a rare case and systematic review of literature. J Matern Fetal Neonatal Med. 2014;27(10):1055-63.

3. Sepulveda W, Alcalde JL, Schnapp C, Bravo M. Perinatal outcome after prenatal diagnosis of placental chorioangioma. Obstet Gynecol. 2003;102:1028-33.

4. Lutgardo García-Díaz, Práxedes Carreto, Susana Costa-Pereira, Guillermo Antinolo. Prenatal management and perinatal outcome in giant placental chorioangioma complicated with hydrops fetalis, fetal anemia and maternal mirror Syndrome. BMC Pregnancy Childbirth. 2012;12:72.

5. Guschmann M, Henrich W, Dudenhausen JW. Chorioangiomas - new insights into a well-known problem. II. An immunohistochemical investigation of 136 cases. J Perinat Med. 2003;31:170-5.
6. Ogino S, Redline RW. Villous Capillary lesions of the placenta: distinctions between chorioangioma, chorioangiomatosis and chorioangiosis. Hum Pathol. 2000;31:945-54.

7. Wou K, Chen MF, Mallozzi A, Brown RN, Shrim A. Pregnancy outcomes and ultrasonographic diagnosis in patients with histologically-proven placental chorioangioma. Placenta. 2011;32:671-4.

8. Sreelakshmi Kodandapani, Abha Shreshta, Vani Ramkumar, Lakshmi Rao. Chorioangioma of placenta: a rare placental cause for adverse fetal outcome. Case Rep Obstet Gynecol. 2012;2012:913878.

9. Kirkpatrick AD, Podberesky DJ, Gray AE, McDermott JH. Placental chorioangioma. Radiographics. 2007;27(4):1187-90.

10. Barros A, Freitas AC, Cabral AJ, Camacho MC, Costa E, Leitão $\mathrm{H}$, et al. Giant placental chorioangioma: a rare cause of fetal hydrops. BMJ Case Rep. 2011;2011:pii: bcr0220113880.

11. Wehrens XH, Offermans JP, Snijders M, Peeters LL. Fetal cardiovascular response to large placental chorioangiomas. J Perinat Med. 2004;32:107-12.

12. Zalel Y, Weisz B, Gamzu R, Schiff E, Shalmon B, Achiron R. Chorioangiomas of the placenta: sonographic and Doppler flowcharacteristics. J Ultrasound Med. 2002;21(8):909-13.

13. Zanardini C, Papageorghiou A, Bhide A, Thilaganathan B. Giant placental chorioangioma: natural history and pregnancy outcome. Ultrasound Obstet Gynecol. 2010;35:332-6.

14. Maymon R, Hermann G, Reish O, Herman A, Strauss S, Sherman D, et al. Chorioangioma and its severe infantile sequelae: case report. Prenat Diagn. 2003;23:976-80.

15. Jauniaux E, Ogle R. Color Doppler imaging in the diagnosis and management of chorioangiomas. Ultrasound Obstet Gynecol. 2000;15:463-7.

16. Abramowicz JS, Sheiner E. In utero imaging of the placenta: importance for diseases of pregnancy. Placenta. 2007;28:S14-22.

17. Blaicher W, Brugger PC, Mittermayer C, Schwindt J, Deutinger J, Bernaschek G, et al. Magnetic resonance imaging of the normal placenta. Eur J Radiol. 2006;57:256-60.

18. Sepulveda W, Wong AE, Herrera L, Dezerega V, Devoto JC. Endoscopic laser coagulation of feeding vessels in large placental chorioangiomas: report of three cases and review of invasive treatment options. Prenat Diagn. 2009;29:201-6.

19. Bhide A, Prefumo F, Sairam S, Carvalho J, Thilaganathan B. Ultrasound-guided interstitial laser therapy for the treatment of placental chorioangioma. Obstet Gynecol. 2003;102:1189-91.

20. Nicolini U, Zuliani G, Caravelli E, Fogliani R, Poblete A, Roberts A. Alcohol injection: a new method of treating placental chorioangiomas. Lancet. 1999;353:1674-5. 
21. Amer HZ, Heller DS. Chorangioma and related vascular lesions of the placenta - a review. Fetal Pediatr Pathol. 2010;29:199-206.

22. Kriplani A, Abbi M, Banerjee N, Roy KK, Takkar D. Indomethacin therapy in the treatment of polyhydramnios due to placental chorioangioma. J Obstet Gynaecol Res. 2001;27:245-8.

23. Sivaslı E, Tekşam Ö, Haliloğlu M, Güçer S, Orhan D, Gürgey A, et al. Hydrops fetalis associated with chorioangioma and thrombosis of umbilical vein. Turk J Pediatr. 2009;51:515-8.
24. Quintero RA, Reich H, Romero R, Johnson MP, Gonçalves L, Evans MI. In utero endoscopic devascularization of a large chorioangioma. Ultrasound Obstet Gynecol. 1996;8:48-52.

DOI: $10.18203 / 2320-1770$. ijrcog20150122

Cite this article as: Marwah S, Bansal N, Gaikwad H, Sharma M. Giant chorioangioma of placenta: an infrequent placental cause for adverse feto-maternal outcome. Int J Reprod Contracept Obstet Gynecol 2015;4:893-7. 